\title{
ANALISA THROUGHPUT JARINGAN 4G LTE DAN HASIL DRIVE TEST PADA CLUSTER RENON
}

\author{
I Dw Gd Paramartha warsika ${ }^{1}$, N.M.A.E. Dewi Wirastuti ${ }^{2}$, Pande Ketut Sudiarta ${ }^{3}$ \\ ${ }^{1,2,3}$ Program Studi Teknik Elektro, Fakultas Teknik, Universitas Udayana \\ Email: dodeparamartha@gmail.com ${ }^{1}$, dewi.wirastuti@unud.ac.id ${ }^{2}$, sudiarta@unud.ac.id $^{3}$.
}

\begin{abstract}
Abstrak
Perkembangan teknologi komunikasi yang sangat pesat khusus pada jaringan $4 \mathrm{G}$ tidak dapat terlepas dari berbagai permasalahan, salah satunya adalah terjadinya kepadatan trafik yang menyebabkan kecepatan saat proses transfer data menurun. Dari permasalahan ini mengangkat topik tentang analisis perbandingan hasil simulasi throughput jaringan 4G LTE dengan hasil drive test pada cluster renon. Pada analisa simulasi menggunakan software Atoll diketahui bahwa luas jangkauan $1.31 \mathrm{~km}^{2}$ dan kecepatan akses data yang ditermia user equipment $4.000 \mathrm{kbps}$ s/d $5.000 \mathrm{kbps}$. Sedangkan analisa hasil drive test menggunakan software G-NetTrack Pro dengan metode dedicated dari data eksisting eNodeB AKABA_PL, MYAMIN_CR, dan BUNDARANRENON_PL. Diketahui rata-rata downlink yang didapat user sebesar 2 Mbps, dengan jarak $100 \mathrm{~s} / \overline{\mathrm{d}} 800$ meter yang dapat ditarik pada setiap sektor eNodeB. Adapun beberapa parameter yang diukur seperti RSRP, RSRQ, SINR dan throughput. Analisis pada hasil drive test ditemukan parameter yang mempengaruhi kecepatan akses saat melakukan download dan beberapa faktor-faktor lain. Selanjutnya parameter throughput kondisi downlink akan dibandingkan dari hasil simulasi dengan data pengukuran dilapangan dan dari perbandingan yang dilakukan diperoleh hasil yang linear.

Kata Kunci: Drive Test, G-NetTrack Pro, Software Atoll, Throughput
\end{abstract}

\section{Abstract}

The development of very rapid communication technology specifically on $4 G$ networks. cannot be separated from various problems, one of which is the occurrence of traffic density which causes transmission data rate decline.Telecommunications services in particular throughput has increased access. From this problem, this paper studies the simulation results of 4G LTE network throughput compared to the results of the drive test on the renon cluster. From the simulation, it known that the coverage area of $1.31 \mathrm{~km}^{2}$ and the speed of data access are termed by the equipment user 4,000 kbps to 5,000 kbps. While the results of drive test analysis using G-NetTrack Pro software with dedicated method from the existing eNodeB AKABA_PL, MYAMIN_CR, and BUNDARANRENON_PL data. The average downlink obtained by users is 2 Mbps, distance 100 to 800 meters that can be drawn on each sector eNodeB. The parameters measured are RSRP, RSRQ, SINR and throughput. Analysis of the drive test results found parameters that affect access speed when downloading and several other factors. Furthermore, the parameters of the downlink throughput was compared to the simulation results with the measurement data in the field and from the comparison made the results are linear.

Keywords: Drive Test, G-NetTrack Pro, Software Atoll, Throughput

\section{PENDAHULUAN}

Perkembangan teknologi komunikasi yang sangat pesat khusus pada jaringan 4G tidak dapat terlepas dari berbagai permasalahan. Layanan telekomunikasi khususnya throughput terjadi peningkatan akses. Dari permasalahan ini mengangkat topik tentang analisis perbandingan hasil simulasi throughput jaringan 4G LTE dengan hasil drive test pada cluster Renon. Analisa yang dilakukan mengenai prediksi throughput saat kondisi downlink, dari prediksi ini diketahui bahwa kecepatan akses data yang akan di terima oleh user equipment. Saat melakukan prediksi software yang digunakan merupakan Radio planning atoll dengan menggunakan data eksisting dari provider PT. Indosat. Hasil prediksi yang didapat berupa luas jangkauan dan kecepatan akses data yang akan diterima user equipment di area Renon.[2]

Setelah melakukan analisa pada hasil simulasi, dilanjukan dengan melalukan drive test, untuk mengetahui kecepatan akses data real dilapangan. Dari pengukuran metode yang digunakan yaitu dedicated, saat pengukuran dilapangan 
melakukan streaming dan proses download file agar dapat diketahui throughput yang diterima oleh user pada area Renon. Adapun beberapa parameter yang diukur saat drive test seperti RSRP, RSRQ, SINR dan throughput, pengukuran dilakukan menggunakan software G-NetTrack Pro. Saat pengambilan data dilakukan pada pagi, sore, dan malam untuk mengetahui kecepatan data yang dapat diakses pada jam kerja maupun jam pulang kerja. Setelah memperoleh hasil drive test di eksport pada google earth untuk megetahui hasil dari pengukuran real dilapangan. Dalam drive test perlengkapan yang diperlukan seperti software pendukung, handphone, dan LTE datacard [1].

Selanjutnya dilalukan analisa terhadap beberapa faktor yang mempengaruhi parameter throughput saat melakukan pengukuran dilapangan. Setelah memperoleh data hasil dari simulasi dan rata-rata hasil drivet test, maka dilakukan perbandingan hasil simulasi dengan pengukuran dilapangan. Ini dilakukan untuk mengetahui seberapa besar selisih kecepatan akses data yang diterima setiap user equipment. Hasil perbandingan akan mengacu pada Standar Key Kerformance Indicator (KPI) [2].

\section{LTE (Long Term Evolution)}

Long Term Evolution merupakan suatu layanan dengan kemampuan tinggi, yang diperkenalakn oleh (3GPP) The Third Generation Partnership Project. Dimana LTE berfungsi sebagai suatu perangkat tambahan pada jaringan Universal Mobile Telecommunications System. Disamping itu keunggulan secara umum Long Term Evolution dapat memberikan kecepatan akses maksimal hingga $50 \mathrm{Mbps}$ saat melaukan Uplink. Sedangkan saat melakukan Downlink kecepatan akses maksimal yang diberikan hingga 100 Mbps.[3]

\subsection{Parameter Unjuk Kerja LTE}

Berikut merupakan mayoritas parameter yang didapat saat pengukuran real dilapangan menggunakan teknologi $4 G$ LTE.[2][4]

\section{Parameter RSRP (Reference Signal Received Power)}

Merupakan parameter kuat signal dari jaringan LTE yang diterima oleh user equipment. Parameter ini berfungsi menentukan titik-titik saat terjadi handover, dan mengetahui luas jangkauan dari sector antenna pada suatu eNodeB. Untuk range parameter RSRP dapat dilihat pada Tabel 1.

Tabel 1. Range Parameter RSRP [6]

\begin{tabular}{|c|c|c|}
\hline \multirow{2}{*}{ Warna } & Nilai RSRP $(\mathrm{dBm})$ & Keterangan \\
\hline & $<-60$ & Luar biasa \\
\hline & $-60 \mathrm{~s} / \mathrm{d}-70$ & Sangat baik \\
\hline & $-70 \mathrm{~s} / \mathrm{d}-80$ & Baik \\
\hline & $-80 \mathrm{~s} / \mathrm{d}-90$ & Normal \\
\hline & $-90 \mathrm{~s} / \mathrm{d}-110$ & Buruk \\
\hline & $-110 \mathrm{~s} / \mathrm{d}-120$ & Sangat Buruk \\
\hline
\end{tabular}

\section{Parameter RSRQ (Reference Signal Received Quality)}

Merupakan kualitas signal yang membantu parameter RSRP saat terjadi handover. Selain itu parameter RSRQ di definisikan sebagai rasio antara jumlah resource block terhadap rata-rata daya linier yang terima oleh user termasuk daya dari serving cell, noise, dan interferensi. Untuk range parameter RSRQ dapat dilihat pada Tabel 2.

Tabel 2. Range Parameter RSRQ [6]

\begin{tabular}{|c|c|c|}
\hline Warna & Nilai RSRQ $(\mathrm{dB})$ & Keterangan \\
\hline & $<2$ & Luar biasa \\
\hline & $2 \mathrm{~s} / \mathrm{d}-1$ & Sangat baik \\
\hline & $-1 \mathrm{~s} / \mathrm{d}-7$ & Baik \\
\hline & $-7 \mathrm{~s} / \mathrm{d}-10$ & Normal \\
\hline & $-10 \mathrm{~s} / \mathrm{d}-14$ & Buruk \\
\hline & $-14 \mathrm{~s} / \mathrm{d}-20$ & Sangat Buruk \\
\hline
\end{tabular}

3. Parameter SINR (Signal to Interference Noise Ratio)

Merupakan kualitas signal yang diterima berupa daya interferensi dan daya noise yang mempengaruhi saat pengiriaman atau penerimaan data yang dilakukan oleh user. Untuk range parameter SINR dapat dilihat pada Tabel 3.

Tabel 3. Range Parameter SINR [6]

\begin{tabular}{|c|c|c|}
\hline Warna & Nilai SINR $(\mathrm{dB})$ & Keterangan \\
\hline & $\geq 20$ & Luar Biasa \\
\hline & $15 \mathrm{~s} / \mathrm{d} 10$ & Sangat Baik \\
\hline & $10 \mathrm{~s} / \mathrm{d} 5$ & Baik \\
\hline & $5 \mathrm{~s} / \mathrm{d} 0$ & Normal \\
\hline & $0 \mathrm{~s} / \mathrm{d}-5$ & Buruk \\
\hline & $<-10$ & Sangat Buruk \\
\hline
\end{tabular}




\section{Parameter Throughput}

Merupakan bandwidth aktual yang terukur pada suatu ukuran waktu tertentu dalam melakukan pengukuran menggunakan rute internet yang spesifik ketika sedang mendownload suatu file. Sedangkan throughput jaringan merupakan tingkat rata-rata keberhasilan pengiriman data melalui saluran komunikasi. Untuk range parameter throughput dapat dilihat pada Tabel 4.

Tabel 4. Range Parameter Throughput [6]

\begin{tabular}{|c|c|c|}
\hline Warna & Nilai Throughput (kbps) & Keterangan \\
\hline & $<10.000$ & Luar biasa \\
\hline & $10.000 \mathrm{~s} / \mathrm{d} 5.000$ & Sangat baik \\
\hline & $5.000 \mathrm{~s} / \mathrm{d} 1.000$ & Baik \\
\hline & $1.000 \mathrm{~s} / \mathrm{d} 384$ & Normal \\
\hline & $384 \mathrm{~s} / \mathrm{d} 128$ & Buruk \\
\hline & $128 \mathrm{~s} / \mathrm{d} 0$ & Sangat Buruk \\
\hline
\end{tabular}

2.2 Unjuk Kerja Parameter Throughput

Pada LTE yang berperan penting yaitu parameter throughput. Berikut bagianbagian yang mempengaruhi kinerja parameter throughput saat kondisi uplink maupun downlink.[3][5]

\section{OFDMA (Orthogonal Frequency Division Multiple Access)}

Merupakan frekuensi yang dipakai pada kondisi downlink jaringan LTE. Disamping itu frekuensi ini mampu beradaptasi di berbagai spectrum pada semua sistem. Dan OFDMA dapat mengurangi ketika terjadinya multipath fading dengan menggunakan sistem antenna MIMO Multiple in Multiple Out.

\section{SCFDMA (Single Carrier Frequency Division Multiple Access)}

Merupakan frekuensi yang sangat cocok dengan uplink, karena uplink memerlukan Peak to Average Power Ratio yang tinggi saat membawa symbol yang akan ditransmisikan dan PAPR yang rendah pada uplink memungkinkan user equipment dapat menjangkau eNodeB yang letaknya jauh sehingga ukuran sel long term evolution menjadi lebih besar.

\section{METODE PENELITIAN}

\subsection{Alur Penelitian Umum}

Berikut merupakan alur analisa secara umum untuk menganalisa data dengan mengunakan langkah-langkah yang sesuai dengan diagram alir seperti pada Gambar 1.

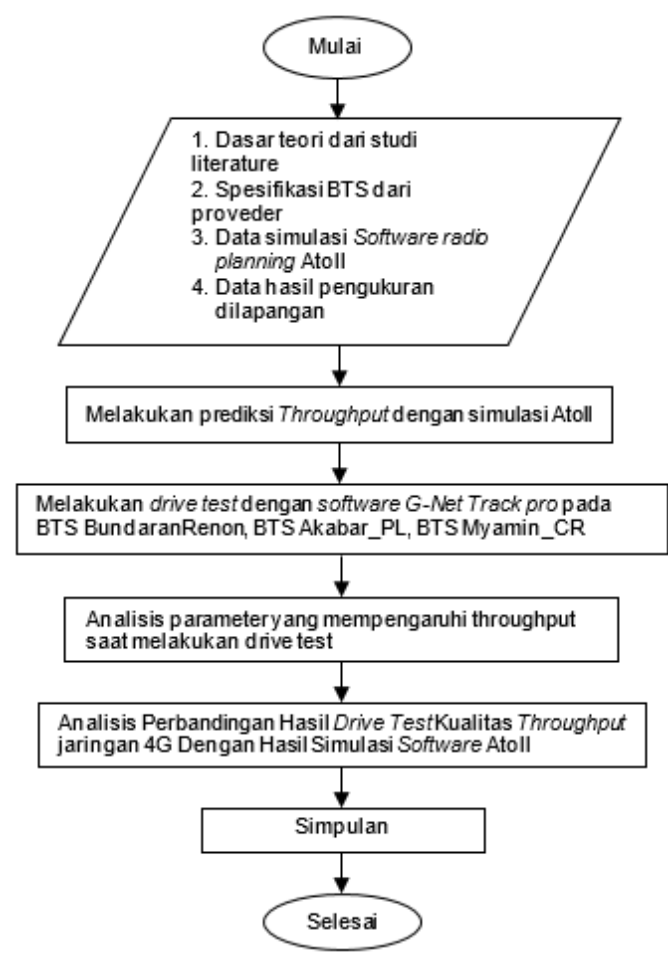

Gambar 1. Alur Penelitian Umum

Berdasarkan diagram alur analisa penelitian pada gambar 1 , penelitian dimulai dengan melakukan studi literatur yang mengarah ke parameter throughput. Selajutnya melalukan simulasi menggunakan atoll untuk melihat coverage dan kecepatan akses yang diterima user saat melakukan download. Proses selanjutnya mencari data hasil dengan pengukuran dilapangan, ada beberapa parameter yang diukur seperti RSRP, RSRQ, SINR dan throughput. Dari hasil drive test dialkukan analisa faktor yang mempengaruhi kecepatan akses data yang ditermia user equipment. Selanjutkan hasil simulasi dibandingkan dengan hasil dari pengukuran dilapangan dengan mengacu pada standar KPI yang didapat dari operator.

\section{HASIL DAN PEMBAHASAN}

4.1 Hasil Simulasi dan Drive Test Parameter Throughput

Pada penelitian ini, dilakukan simulasi coverage by throughput menggunakan software atoll. Saat simulasi data yang digunakan merupakan data eksisting dari proveder PT. Indosat. Dimana hasil simulasi menjukkan kecepatan akses data yang diterima dalam katagori "Normal dan Baik". Disamping itu ada perumpamaan beberapa variable yang dilakukan untuk 
mengetahui apakah dengan itu dapat mengubah hasil dari throughput pada kondisi downlink. Pada Gambar 2 menunjukkan hasil simulasi dari parameter throughput.

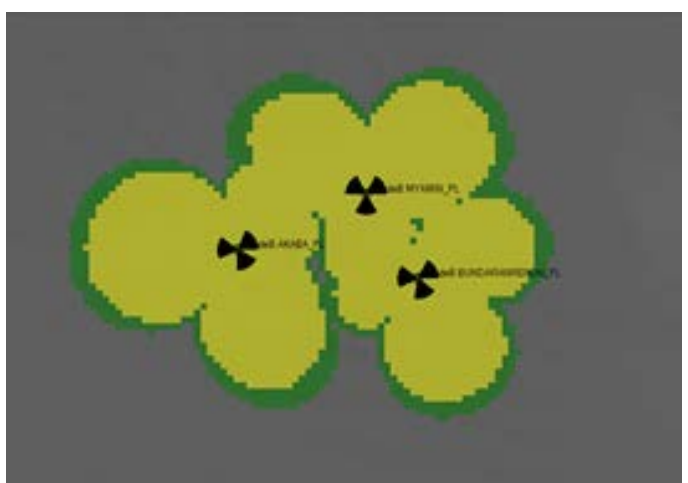

Gambar 2. Hasil Simulasi parameter Throughput saat downlink

Dari Gamabar 2 diatas dapat dilihat bahwa wilayah Renon atau Cluster Renon telah mencakup jaringan yang disimulasikan. Prediksi parameter throughput khususnya saat downlink menghasilkan berbedaan warna dalam coverage menghasilkan warna (kuning dan hijau). Salah satunya didapatkan sinyal berwarna kuning dan hijau tua, dari kedua warna menunjukkan baik atau buruknya kecepatan akses data yang diterima oleh User equipment. Berdasarkan hasil simulasi diketahui dari ketiga site (transmitter) tersebut masuk dalam coverage yang menandakan downlink yang diterima berkisar antara $4.000 \mathrm{kbps} \mathrm{s} / \mathrm{d}$ 5.000 kbps dikatagorikan dalam kondisi "Baik" merujuk pada tabel 4 dan rata-rata luas jangkauan sekitar $2 \mathrm{~km}$.

Selanjutnya pengambilan data dengan drive test yang dilakukan pada waktu pagi, sore dan malam. Pengukuran yang dilakukan berdasarkan eNodeB eksisting. Ini berlangsung pada tanggal 20 September 2018. Grafik dari nilai rata-rata dari ketiga waktu pengukuran dapat dilihat pada Gambar 3, 4 dan 5.

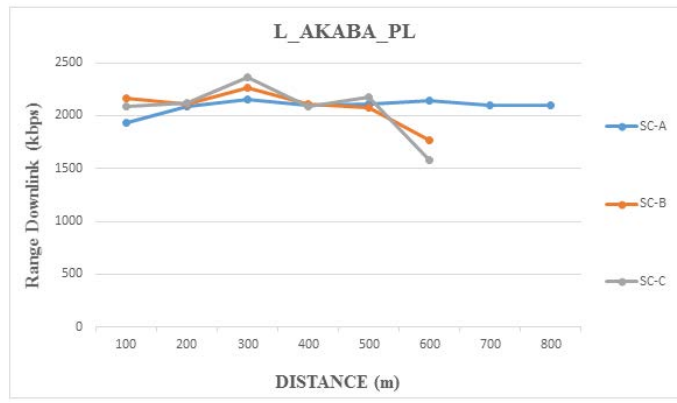

Gambar 3. Grafik eNodeB L_Akaba_PL

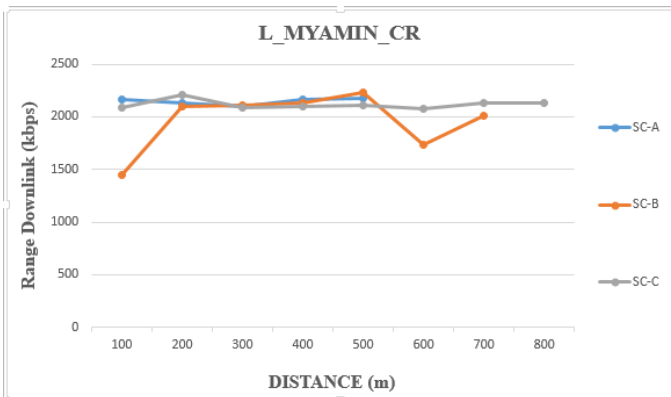

Gambar 4. Grafik eNodeB L_Myamin_CR

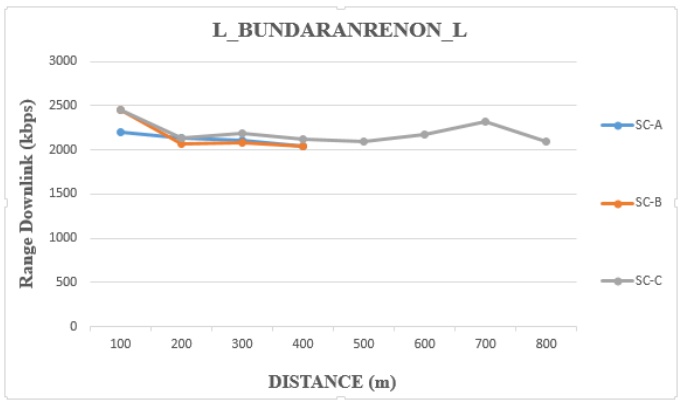

Gambar 5. Grafik eNodeB L_BundaranRenon_PL

Pada Gambar 3 hasil downlink dari drive test menunjukkan di setiap sektor lebih dominan menperoleh nilai yang dikatakan "Baik" merujuk pada Tabel 4. Dengan nilai rata-rata saat pengukuran dilapangan, pada eNodeB L_Akaba_PL memperoleh 2.070 kbps. Pada eNodeB $\mathrm{L}$ Myamin CR memperoleh nilai rata-rata sébesar 2.071 kbps. Sedangkan pada eNodeB L_BundaranRenon_PL memperoleh $2.170 \mathrm{kbps}$. Dengan jarak titik yang diambil dari $100 \mathrm{~s} / \mathrm{d} 800$ meter.

Adapun di beberapa jarak tidak memperoleh hasil saat pengukuran, karena sudah di serving oleh eNodeB tetangga. Disamping itu pengukuran dengan software G-Net Track Pro tidak bisa melakukan lock eNodeB. Dari pengukuran yang dilakukan ditemukan beberapa Penyebab penurunan kecepatan akses data saat kondisi downlink, karena metode dedicated terjadinya delay pada download file yang dilakukan saat drive test. Selain itu faktor dari sensitivitas perangkat juga mempengaruhi hasil saat pengukuran, seperti yang dapat dilihat pada gambar 6 


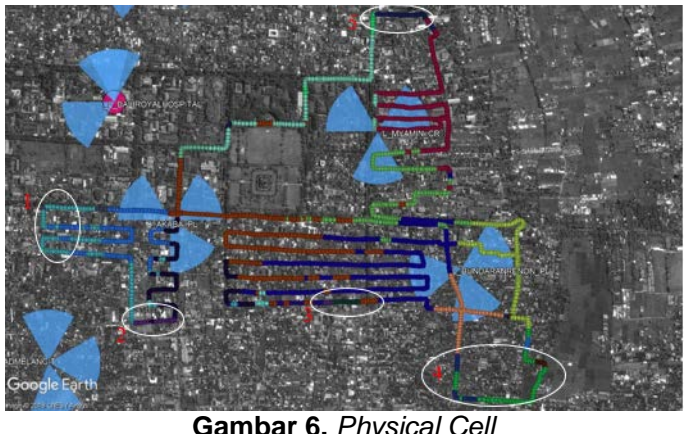

Terlihat pada gambar rute yang dilalui saat drive test dan ada variasi warna di titiktitik pengukuran. Ketiga sektor pada eNodeB mewakili warna yang berbedabeda, seperti eNodeB L_BundaranRenon_PL SC-C berwarna biru, sc-a berwarna kuning tua, sc-b berwarna orange, dan lain-lain. Untuk tanda no 1 menunjukkan eNodeB L_Akaba_PL, sc-c ada beberapa titik yang di serving oleh eNodeB L BaliRoyalHospital, sc-b tanda no 2 telā di serving eNodeB L_TukadMelangit. Pada tanda no 3 eNodeB L_BundaranRenon_PL, SC-C di serving oleh e NodeB L_Tukad̄Ayung dan eNodeB L_TukadMelangit_PL, karena ada dua warna berbeda yang didapat saat pengukuran, dan tanda no 4 di sc-c telah di serving eNodeB L_TukadBalian_TB. Untuk tanda no 5 yang ada pada sc-a eNodeB L_Myamin_CR telah di serving eNodeB L-Narakusuma dan eNodeB L_TanjungBungkak_CR. Adapun beberapa kendala pada rute dilapangan, dimana rute yang dilalui merupakan jalan pribadi penduduk sekitar dan jalan buntu.

Selanjutnya didapat grafik dari sampel ketiga eNodeB eksisting yang dilakukan saat drive test yaitu parameter RSRP, RSRQ, SINR dan throughput seperti yang dapat dilihat pada Gambar 7.

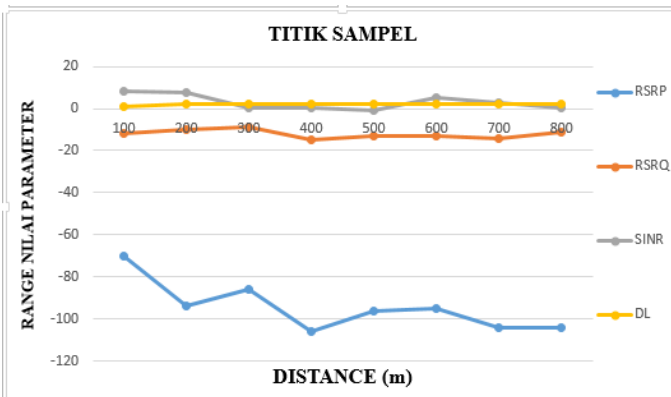

Gambar 7. Grafik Perbandingan Nilai Parameter RSRP, RSRQ, SINR, dan Throughput
Berikut beberapa sampel titik dari pengukuran yang mendapat kondisi ekstrem seperti yang ditunjukkan pada Tabel 5.

Tabel 5. Nilai Parameter Dari Sampel Titik Pengukuran

\begin{tabular}{|c|c|c|c|c|c|}
\hline Jarak & eNodeB & $\begin{array}{c}\text { RSRP } \\
(\mathrm{dBm})\end{array}$ & $\begin{array}{c}\text { RSRQ } \\
(\mathrm{dB})\end{array}$ & $\begin{array}{c}\text { SINR } \\
(\mathrm{dB})\end{array}$ & $\begin{array}{c}\text { DL } \\
(\mathrm{kbps})\end{array}$ \\
\hline 100 & $\begin{array}{c}\text { L_Akaba_PL } \\
\text { SC-a }\end{array}$ & -76 & -8 & 13 & 4 \\
\hline 100 & $\begin{array}{c}\text { L_Akaba_PL } \\
\text { SC-b }\end{array}$ & -78 & -8 & 11 & 4 \\
\hline 200 & $\begin{array}{c}\text { L_Akaba_PL } \\
\text { Sc-C }\end{array}$ & -77 & -8 & 12 & 4 \\
\hline 200 & $\begin{array}{c}\text { L_Myamin_CR } \\
\text { sc-b }\end{array}$ & -83 & -7 & 21 & 4 \\
\hline 300 & $\begin{array}{c}\text { L_Myamin_CR } \\
\text { sc-c }\end{array}$ & -86 & -8 & 11 & 36 \\
\hline 100 & $\begin{array}{c}\text { L_BundaranRenon_PL } \\
\text { SC-a }\end{array}$ & -84 & -9 & 22,7 & 4 \\
\hline 200 & $\begin{array}{c}\text { L_BundaranRenon_PL } \\
\text { Sc-b }\end{array}$ & -84 & -9 & 13,2 & 4 \\
\hline 400 & $\begin{array}{c}\text { L_BundaranRenon_PL } \\
\text { sc-C }\end{array}$ & -86 & -8 & 24 & 4 \\
\hline
\end{tabular}

Tabel 5 merupakan kondisi ekstrim dari pengukuran. Dimana kuat sinyal dan kualitas sinyal dapat dikatakan katagori "Baik" mengacu pada tabel 1, 2 dan 3, namun hasil parameter throughput mendapat hasil yang "buruk" mengacu pada tabel 4.

Selanjutnya hasil perbandingan dari kondisi downlink eNodeB, antara drive test menggunakan G-NetTrack Pro dengan simulasi menggunakan software radio planning Atoll. Hasil perbandingan berdasarkan dari nilai rata-rata dari ketiga waktu pengukuran eNodeB dan Sector (SC), seperti yang ditunjukkan pada Gambar 8, 9 dan 10.

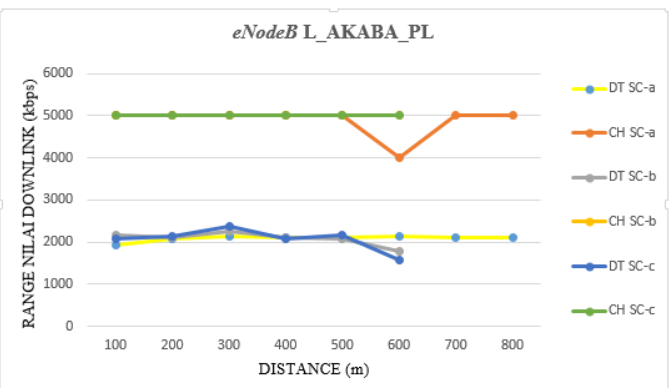

Gambar 8. Grafik Perbandingan Nilai Downlink eNodeB L_Akaba_PL

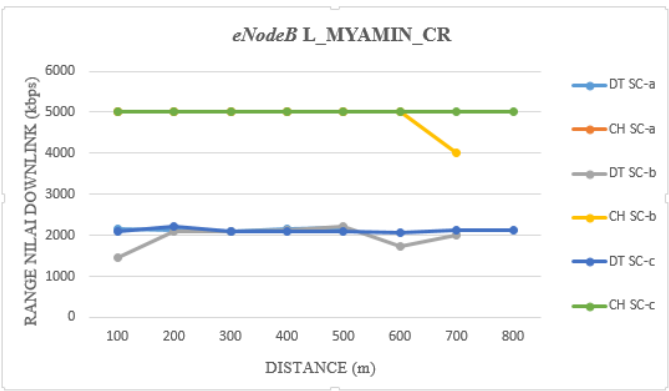


Gambar 9. Grafik Perbandingan Nilai Downlink eNodeB L_Myamin CR

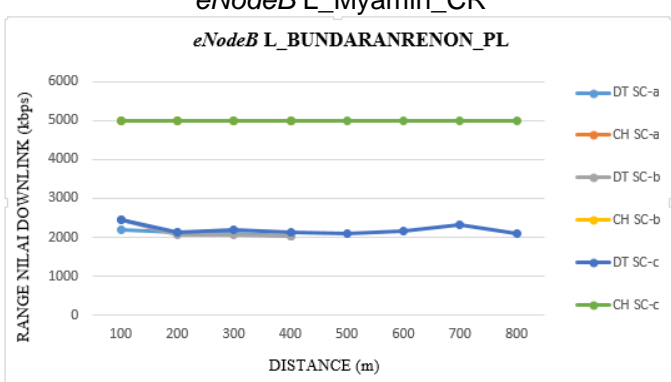

Gambar 10. Grafik Perbandingan Nilai Downlink eNodeB L_BundaranRenon_PL

Hasil pada Gambar 8, 9 dan 10 menunjukkan grafik dari hasil perbandingan antara pengukuran dengan simulasi dari ketiga eNodeB. Terlihat hasil perbandingan tersebut memiliki hasil downlink yang berbeda, dimana rata-rata pengukuran mendapat hasil 2 Mbps dan simulai mendapat $5 \mathrm{Mbps}$. Dari perbandingan yang didapat menyatakan bahwa hasil parameter throughput dalam kondisi downlink masih dalam range kategori "baik" merujuk pada tabel 4 dan hasil disemua jarak mendapat hasil yang linear.

\subsection{Pembahasan}

Pada simulasi mendapat nilai yang linear karena saat simulasi hanya satu user yang mengakses ketiga sector, dan tidak memperhitungkan adanya interferensi. Adapun kelengkapan data yang didapat maka penulis melakukan perumpamaan variable seperti pengaturan power antenna, frekuensi, dan propagasi di setiap sector. Namun nilai yang didapat tetap linear dan yang berubah hanya coverage setiap sector di ketiga EnodeB

Pada drive test dapat di analisa hubungan antara RSRP, RSRQ dan SINR terhadap throughput.

1. Parameter RSRP berpengaruh pada coverage dari ketiga eNodeB, hasil RSRP dalam katagori "buruk" tidak mempengaruhi hasil throughput saat pengukuran karena parameter RSRP merupakan power sinyal yang berpengaruh terhadap coverage dari eNodeB, dimana semakin jauh UE mengakses suatu eNodeB maka akan semakin buruk power yang diterima.

2. Parameter RSRQ tidak berpengaruh terhadap hasil dari parameter throughput berdasarkan dari pengamatan di lapangan dan persamaan 2.3, dimana kualitas sinyal pada RSRQ dapat meranking performansi kandidat sel dalam proses cell selection - reselection dan handover, kedua parameter ini berpengaruh signifikan.

3. Parameter SINR merupakan salah satu kualitas yang mempengaruhi parameter throughput, dimana parameter SINR berperan terhadap skema modulasi dari eNodeB ke user equipment berdasarkan pengamatan yang dilakukan saat drive test dan berdasarkan dari persamaan pada sub-bab 2.7.4.

Ada beberapa faktor yang ditunjukkan gambar 7 terjadinya penurunan nilai throughput, seperti faktor adanya obstacle, karena saat drive test ditemukan ada beberapa bangunan yang tinggi \pm 20 meter dan pepohonan. Namun ada kemungkinan penurunan terjadi karena traffic yang padat. Dan saat melalukan pengamatan penurunan terjadi disebabkan delay saat download file pada pengukuran dan kapasitas kouta internet yang tersedia pada perangkat.

\section{KESIMPULAN}

Dari penelitian yang dilakukan dapat disimpulkan bahwa nilai rata-rata yang didapat dari simulasi diketiga eNodeB masih dalam range kategori "Baik". Dengan model propagasi Cost231 Hatta, dengan jangkauan coverage area yang dihasilkan $1.31 \mathrm{~km}^{2}$. Dari pengukuran menggunakan G-NetTrack diperoleh nilai maksimal sebesar 2 Mbps dengan range kategori "Baik" dan jarak maksimum yang dapat diukur yaitu 800 meter.

Pada parameter RSRP, RSRQ, dan SINR yang di analisa diketahui bahwa parameter SINR berpengaruh signifikan terhadap hasil parameter throughput. Sedangkan parameter RSRP akan berpengaruh signifikan terhadap RSRQ. Dan parameter SINR yang mempengaruhi hasil dari parameter throughput secara signifikan. Adapun faktor lain yang mempengaruhi parameter throughput seperti, kepadatan traffic, obstacle, delay dan kapasitas kouta internet yang tersedia. Selanjutnya hasil perbandingan simulasi dengan drive test, mendapat hasil yang mendekati pengukuran diperoleh sebesar $1.862 \mathrm{kbps}$ dan hasil yang jauh dari pengukuran diperoleh sebesar 3.554 kbps. 


\section{DAFTAR PUSTAKA}

[1] Kusumo, V.S. 2015. "Analisis Performansi Dan Optimalisasi Coverage Layanan LTE Telkomsel Di Denpasar Bali. E-Journal SPEKTRUM. Vol.2. 12-18

[2] S.G.Y.P. Putra, P.K. Sudiarta, G. Sukadarmika 2018. Analisis Hasil Drive Test Menggunakan Software Genex Probe Dan Genex Assistant Pada Jaringan LTE. E-Journal SPEKTRUM Vol. 5, No. 1 Juni 2018.

[3] R. Yanuari, P.K. Sudiarta, N. Gunantara. 2015. "Analisa Kualitas Sinyal Jaringan GSM Pada Menara Rooftop dengan Membandingkan Aplikasi Metode Drive Test antara TEMS Investigation 8.0.3 dengan GNettrack Pro". E-Journal SPEKTRUM Vol. 2, No. 4 Desember 2015.

[4] Ketut Alit Winaya. 2016 "Analisis Kajian Penataan Sel Untuk Memperbaiki Cakupan Layanan Sistem WCDMA Di Aera Jalan Tengah I Kerobokan". Denpasar: Universitas Udayana

[5] Hikmaturokhman, Alfin. 2014. "4G LTE Drive Test". 4G Handbook Edisi Bahasa Indonesia. Jakarta: Nulis buku.

[6] http://www.gyokovsolutions.com/man uals/gnettrackpro_manual.php, akses tanggal 14 Januari 2019 